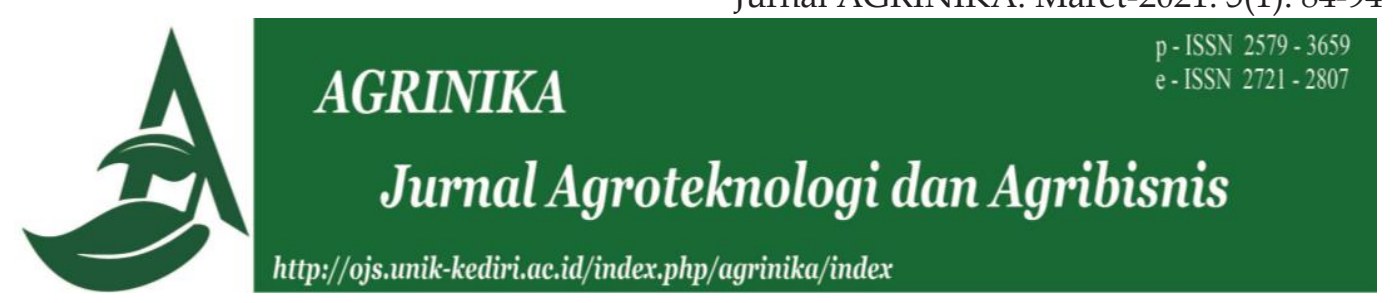

\title{
Upaya Optimalisasi Hasil Panen Padi Menggunakan Berbagai Model Jarak Tanam Dan Dosis Pupuk Kandang
}

\author{
Junaidi ${ }^{1 *}$, Djoko Rahardjo ${ }^{1}$ \\ ${ }^{1}$ Fakultas Pertanian, Universitas Kadiri, Kediri, Indonesia \\ *Korespodensi: junaidi@unik-kediri.ac.id \\ Diterima 14 Februari 2021/Direvisi 26 Februari 2021/Disetujui 6 Maret 2021
}

\begin{abstract}
ABSTRAK
Isi artikel ini bertujuan mengetahui adanya interaksi yang nyata antara perlakuan dosis bokasi dan model jarak tanam terhadap pertumbuhan dan hasil tanaman padi. Penelitian menggunakan rancangan acak kelompok (RAK) faktorial $3 \times 3$ dengan 3 kali ulangan. Faktor pertama adalah model jarak tanam yang terdiri dari 3 taraf, yaitu $\mathrm{J} 1=$ model jarak tegel $(20 \times 20 \mathrm{~cm})$, J2 = Jajar Legowo $4: 1(20 \mathrm{~cm} \times 40 \mathrm{~cm} \times 10 \mathrm{~cm})$, dan J3 = Jajar Legowo 2: $1(20 \mathrm{~cm} \times 40 \mathrm{~cm} \times 10 \mathrm{~cm})$. Faktor kedua adalah dosis pupuk bokashi yang terdiri dari 3 taraf yaitu $\mathrm{P} 1=5$ ton/ha, $\mathrm{P} 2=10$ ton/ha, dan $\mathrm{P} 3=15$ ton/ha. Riset yang dilakukan membuktikan bahwa adanya pengaruh interaksi pada tanaman umur 45 hari serta peningkatan hasil panen berupa berat gabah per rumpun yang mengalami kenaikan. Perlakuan model juga memiliki pengaruh nyata terhadap tinggi tanaman pada usia 15 dan 30 hari sejak masa tanam. Selain itu juga adanya perubahan pada jumlah anakan, anakan produktif, biji per malai, panjang malai, dan berat gabah per petak semua umur pengamatan. Perlakuan model jajar legowo $4: 1$ menghasilkan pertumbuhan dan produksi padi sawah pertanaman paling baik, sedangkan produksi paling tinggi dihasilkan oleh perlakuan jajar legowo 2 : 1. Perlakuan dosis bokasi 15 ton/ha.
\end{abstract}

Kata kunci: Dosis bokasi; Model jarak tanam; Produksi padi

\begin{abstract}
This research aims to determine the real interaction between bokashi dose treatment and spacing models on the growth and yield of paddy plants. The study used a $3 \times 3$ factorial with 3 replications. The first factor was the spacing model which consists of 3 levels, namely $\mathrm{J} 1$ = tile spacing model $(20 \times 20 \mathrm{~cm}), \mathrm{J} 2=$ Jajar Legowo $4: 1(20 \mathrm{~cm} \times 40 \mathrm{~cm} \times 10$ $\mathrm{cm})$, and $\mathrm{J} 3=$ Jajar Legowo $2: 1(20 \mathrm{~cm} \times 40 \mathrm{~cm} \times 10 \mathrm{~cm})$. The second factor was the dosage of bokashi fertilizer which consists of 3 levels, namely P1 $=5$ tonnes per hectare, P2 $=10$ tonnes per hectare, and P3 = 15 tonnes per hectare. The research discovered that there was an interaction effect on plants aged 45 days after planting as well as an increase in yield in the form of an increase in grain weight per plant clump. Model treatment also had a significant effect on plant height at the age of 15 and 30 days after planting. In addition, there were also changes in the number of tillers, productive tillers, seeds per panicle, panicle length, and grain weight per plot for all observed ages. The $4: 1$ legowo row model treatment resulted in the best growth and production of paddy fields, while the highest production was produced by the legowo row 2:1 treatment. Bokashi dosage treatment was 15 tons per hectare.
\end{abstract}

Keywords: Bokashi dosage; Plant spacing model; Paddy production 


\section{PENDAHULUAN}

Bahan pangan utama hampir seluruh penduduk Indonesia, adalah beras yang berasal dari tanaman padi (Azahari dan Hadiutomo, 2016). Terjadi peningkatan konsumsi beras per kapita sejak maret 2017 dibanding dengan periode sebelumnya, peningkatan sekitar 0,6 kg atau dari 97,2 kg menjadi $98 \mathrm{~kg}$ perkapita (Badan Pusat Statistik, 2017). Hal ini disebabkan oleh semakin luasnya lahan yang dipanen seluas 0,32 Juta Hektar (2,31\%) disbanding tahun sebelumnya. Selain itu juga terjadinya peningkatan produktivitas sebesar 3,97\% atau 2,04 kuiantal per hektar(BPS dan BPPT, 2018)

Salah satu faktor penting untuk peningkatan produksi adalah pemupukan (Sari et al., 2017). Akan tetapi pemupukan yang dilakukan sebagaian besar petani dengan pupuk kimia (Sulaeman et al., 2017). Pemupukan dengan bahan kimia juga semakin banyak digunakan oleh petani, tanpa disadari menyebabkan ketidakseimbangan komponen pada tanah (Suyamto, 2017)

Apabila penggunaan pupuk kima pada lahan pertanian dilakukan secara terus menerus maka kandungan bahan organik di dalam tanah juga mengalami penurunan (Neneng dan Jubaedah, 2014). Maka tanpa disadari produktivitas lahan akan menurun juga (Auliana et al., 2018). Pelandaian produktivitas padi (leveling off) adalah bentuk nyata dari ketidakseimbangan unsur hara dikarenakan penggunaan pupuk kimia secara terus menerus (kotu, et al., 2015). Pada 20 tahun terakhir mulai terjadi leveling off produksi padi terakhir sebagai indikasi penurunan efisiensi penggunaan pupuk (Prabowo dan Subantoro, 2017)

Surplus beras setiap tahunnya menjadi target pemerintah (Pratama et al., 2019). Budidaya yang baik juga perlu dilakukan dalam mencapai target tersbut (Nurcahyani dan Saptono, 2016). Penggunaan pupuk organik (bokasi) serta ditunjang dengan pengaturan jarak tanam sebagai bagian dari budidaya yang baik pada tanaman padi (Malian, 2017)

\section{BAHAN DAN METODE}

Riset ini dimulai November 2020 hingga bulan Februari 2021 di Desa Jantok, Kecamatan Purwoasri, Kabupaten Kediri.

Riset ini menggunakan bahan bahan seperti padi varietas Ciherang, Bokasi, Urea, Pupuk NPK Phonska, pestisida Prevathon 50 SC, Seltima 100 CS, Applaud 10 WP. Riset ini juga ditunjang dengan peralatan berupa bajak, garu, cangkul, landak, tali rafia, penggaris, timbangan.

Metode Rancangan Acak Kelompok (RAK) dengan 2 faktor perlakuan digunakan dalam riset ini.

Faktor pertama yaitu model jarak tanam (J ) sebagai berikut :

J1 : Model jarak tanam Tegel $(20 \mathrm{~cm} \mathrm{x}$ $20 \mathrm{~cm}$ )

J2 : Jajar Legowo $4: 1(20 \mathrm{~cm} \times 40 \mathrm{~cm} \times$ $10 \mathrm{~cm}$ )

J3 : Jajar Legowo 2 : $1(20 \mathrm{~cm} \times 40 \mathrm{~cm} \mathrm{x}$ $10 \mathrm{~cm}$ )

Faktor kedua dosis pupuk bokasi terdiri dari :

$\mathrm{P} 1: 5$ ton/ha

P2 : 10 ton/ha

P3 : 15 ton/ha 


\section{HASIL DAN PEMBAHASAN}

Tabel 1 menunjukan bahwa perlakuan model jarak tanam serta dosis pupuk bokasi tidak menunjukan adanya pengaruh interaksi yang nyata terhadap tinggi tanaman pada umur 15 hari dan 30 hari. Sedangkan pada umur penga- matan 45 hari terjadi interaksi antara perlakuan model jarak tanam dan dosis bokasi terhadap tinggi tanaman. Hasil uji BNT $5 \%$ pengaruh model jarak tanam dan dosis bokasi terhadap tinggi tanaman dapat dilihat pada Tabel 1, dan 2.

Tabel 1. Pengaruh perlakuan model jarak tanam dan dosis bokasi terhadap tinggi tanaman umur 45 hari.

\begin{tabular}{ccr}
\hline No. & Perlakuan & Tinggi Tanaman $(\mathbf{c m})$ Umur 45 hari \\
\hline 1. & J1P1 & $84,33 \mathrm{a}$ \\
2. & J1P2 & $88,00 \mathrm{bc}$ \\
3. & J1P3 & $90,33 \mathrm{~cd}$ \\
4. & J2P1 & $87,33 \mathrm{~b}$ \\
5. & J2P2 & $90,67 \mathrm{~d}$ \\
6. & J2P3 & $93,67 \mathrm{e}$ \\
7. & J3P1 & $90,67 \mathrm{e}$ \\
8. & J3P2 & $98,33 \mathrm{f}$ \\
9. & J3P3 & $105,33 \mathrm{~g}$ \\
\hline
\end{tabular}

Keterangan : Angka-angka diikuti oleh huruf yang sama pada kolom yang sama tidak berbeda nyata pada uji BNT ( $\mathrm{pl}=0,05$ )

Tabel 1 diatas menggambarkan kombinasi perlakuan model jarak tanam legowo 2:1 dengan dosis Bokasi 15 ton/ha (J3P3) menghasilkan tanaman tertinggi, yaitu setinggi 105,33 $\mathrm{cm}$ dan diikuti kombinasi perlakuan jajar legowo 2:1 dengan dosis 10 ton/ha (J3P2) setinggi 98,33 cm. Perlakuan J3 akan menyebabkan pemanfaatan energi matahari menjadi lebih baik dari pada J1 (Aribawa, 2012). Selain itu penggunaan model jarak tanam jajar legowo 2:1 berpeluang memiliki populasi padi yang banyak dibandingkan J2 (Ikhwani et al., 2013). Keadaan ini akan menjadi lebih baik bila kedalamnya diberikan pupuk bokasi yang cukup, yaitu 15 ton/ha (P3), karena akan menyebabkan terjadinya penambahan unsur hara ke dalam tanah yang cukup banyak (Rozen dan Kasim, 2018). Sehingga pertumbuhan tanaman akan lebih baik bila dibanding dengan kombinasi perlakuan yang lain.

Tabel 2 diatas dapat menunjukan model J2 dan J3 menghasilkan tanaman yang banyak daripada model $\mathrm{J} 1$, hal ini karena pada perlakuan ini terjadi pemanfaatan energi sinar matahari yang lebih baik dari pada perlakuan model jarak tanam tegel. Sinar matahari dapat lebih masuk kedalam pertanaman.

Perlakuan model J2 memiliki tanaman lebih tinggi daripada model J3. karena pada perlakuan J2, sinar matahari dapat lebih leluasa masuk kedalam pertanaman padi, sehingga pertumbuhan tanaman padi akan lebih baik.

Tabel 2 diatas juga menunjukan bahwa semakin banyak dosis bokasi diberikan pada lahan tanaman padi 
Junaidi \& Djoko Rahardjo, Upaya Optimalisasi Hasil...

Tabel 2. Pengaruh perlakuan model jarak tanam dan dosis bokasi terhadap tinggi tanaman umur 15 dan 30.

\begin{tabular}{crlrl}
\hline \multirow{2}{*}{ Perlakuan } & \multicolumn{5}{c}{ Tinggi tanaman (cm) umur } \\
\cline { 2 - 6 } & 15 hst & 30 hst & \\
\hline J1 & 30,44 & a & 60,56 & a \\
J2 & 35,56 & c & 67,67 & c \\
J3 & 32,44 & b & 64,44 & b \\
BNT 5\% & 1,999 & 2,26 & \\
P1 & 30,33 & a & 60,89 & a \\
P2 & 32,89 & b & 64,44 & b \\
P3 & 35,22 & c & 67,33 & c \\
\hline BNT 5\% & 1,999 & 2,26 & \\
\hline
\end{tabular}

Keterangan : Angka-angka diikuti oleh huruf yang sama pada kolom yang sama tidak berbeda nyata pada uji BNT ( $\mathrm{pl}=0,05$ )

menyebabkan pertumbuhan tanaman yang lebih baik, karena semakin banyak dosis bokasi akan menyebabkan bertambahnya unsur hara yang pada akhirnya menghasilkan tanaman yang lebih tinggi. Tanaman tertinggi secara urutan tertinggi adalah model P3, kemudian model P2, dan model P1.

Jumlah Anakan

Jumlah anakan adalah semua anakan yang dihasilkan oleh tanaman induk tiap rumpun, baik anakan primer, sekunder, maupun tersier (Winarsih et al., 2017). Pada umur pengamatan 15 hari setelah tanam model jarak tanam dan dosis bokasi tidak berpengaruh terhadap jumlah anakan. Pada umur pengamatan 30 dan 45 hari, perlakuan model jarak tanam dan dosis bokasi berpengaruh terhadap jumlah anakan. Perlakuan model jarak tanam dan dosis bokasi terhadap jumlah anakan tanaman terdapat di Tabel 3.

Tabel 3. Jumlah anakan padi akibat berbagai perlakuan

\begin{tabular}{cccccc}
\hline \multirow{2}{*}{ Perlakuan } & \multicolumn{5}{c}{ Jumlah Anakan (batang) pada umur } \\
\cline { 2 - 6 } & $\mathbf{1 5}$ hari & $\mathbf{3 0}$ hari & $\mathbf{4 5}$ hari & \\
\hline J1 & 5,78 & 15,22 & $\mathrm{a}$ & 15,44 & $\mathrm{a}$ \\
J2 & 6,78 & 20,78 & $\mathrm{~b}$ & 20,67 & $\mathrm{~b}$ \\
J3 & 5,78 & 16,67 & $\mathrm{a}$ & 16,78 & $\mathrm{a}$ \\
\hline BNT 5\% & tn & 2 & & 2,23 & \\
\hline P1 & 5,89 & 15,22 & $\mathrm{a}$ & 15,22 & $\mathrm{a}$ \\
P2 & 5,89 & 17,44 & $\mathrm{~b}$ & 17,67 & $\mathrm{~b}$ \\
P3 & 6,56 & 20 & $\mathrm{C}$ & 20,00 & $\mathrm{c}$ \\
\hline BNT 5\% & tn & 2 & & 2,23 & \\
\hline
\end{tabular}

Keterangan : Angka-angka diikuti oleh huruf yang sama pada kolom yang sama tidak berbeda nyata pada uji BNT ( $\mathrm{pl}=0,05$ )

Tabel 3 menunjukan model jarak tanam dan dosis pupuk bokasi tidak berpengaruh kepada jumlah anakan umur 15 hari tanam. Hal ini berarti perlakuan model jarak tanam dan dosis bokasi belum menunjukan adanya pengaruh yang nyata, karena memang 
Junaidi \& Djoko Rahardjo, Upaya Optimalisasi Hasil...

tanaman masih relatif masih kecil (Hamid, 2019).

Model J2 memiliki jumlah anakan yang lebih banyak model lain, karena pada perlakuan $\mathrm{J} 2$ ruang kosong tanpa tanamannya lebih banyak. Pembentukan jumlah anakan sangat dipengaruhi oleh ketersediaan ruang untuk hidup (Wahyudi et al., 2014).

Perlakuan dosis P3 menghasilkan anakan yang banyak dibanding perlakuan dosis P2. Sedangkan perlakuan dosis P2 menghasilkan anakan lebih banyak dari pada perlakuan dosis P1. Hal disebabkan karena semakin banyak dosis bokasi yang diberikan kedalam tanah akan menyebabkan penambahan unsur-unsur hara bagi tanaman yang cukup untuk menunjang pertumbuhan padi (Kriswanto et al., 2016).

Jumlah Anakan Produktif

Jumlah anakan produktif adalah semua anakan baik anakan primer sekunder maupun tersier yang menghasilkan malai dalam setiap rumpun (Mariyono, 2017). Berdasarkan Tabel 3 ternyata tidak menunjukan adanya pengaruh interaksi yang nyata antara perlakuan model jarak tanam dan dosis bokasi terhadap jumlah anakan produktif. Perlakuan model jarak tanam dan dosis bokasih secara terpisah berpengaruh terhadap jumlah anakan produktif. Hasil uji beda nyata terkecil BNT 5\% untuk lebih jelasnya disajikan pada Tabel 4 berikut ini.

Tabel 4. Rata-rata jumlah anakan produktif akibat berbagai perlakuan

\begin{tabular}{crl}
\hline Perlakuan & Jumlah Anakan Produktif umur( Batang) \\
\hline J1 & 13,36 & $\mathrm{a}$ \\
J2 & 19,33 & $\mathrm{c}$ \\
J3 & 15,89 & $\mathrm{~b}$ \\
\hline BNT 5\% & 2,29 & \\
\hline P1 & 13,78 & $\mathrm{a}$ \\
P2 & 16,06 & $\mathrm{~b}$ \\
P3 & 18,44 & $\mathrm{c}$ \\
\hline BNT 5\% & 2,29 &
\end{tabular}

Keterangan : Angka-angka diikuti oleh huruf yang sama pada kolom yang sama tidak berbeda nyata pada uji BNT ( $\mathrm{pl}=0,05$ )

Tabel 4 menunjukkan bahwa perlakuan J1 menghasilkan jumlah anakan produktif lebih sedikit perlakuan lainnya. Hal ini disebabkan karena pada perlakuan jajar legowo sinar matahari dapat masuk ke dalam pertanaman lebih leluasa dari pada perlakuan model $\mathrm{J} 1$, sehingga pertumbuhan tanamannya pada perlakuan lainnya lebih baik dan memliki lebih banyak jumlah anakan produktifnya (Arifiani et al., 2018). Perlakuan P2 memiliki jumlah anakan produktif lebih banyak dari pada model
P3, karena pada model P2 menghasilkan ruang untuk masuknya sinar matahari ke pertanaman lebih banyak bila dibandingkan dengan model P3, sehingga jumlah anakan produktif yang dihasilkan oleh perlakuan P2 lebih banyak dari perlakuan P3.

Dosis pupuk bokasi juga memiliki pengaruh pada jumlah anakan produktif. Pada dosis P2 menghasilkan lebih banyak dari pada dosis $P 1$, sedang tanaman padi yang diberi dosis P3 menghasilkan jumlah anakan produktif 
Junaidi \& Djoko Rahardjo, Upaya Optimalisasi Hasil...

lebih banyak dari pada dosis P2. Semakin tinggi dosis pupuk bokasi yang diberikan kepertanaman padi menyebabkan pertumbuhan tanaman padi lebih baik, sehingga jumlah anakan produktif yang dihasilkan oleh dosis P3 lebih banyak bila dibandingkan dengan dosis P2. Jumlah anakan produktif yang dihasilkan oleh tanaman yang diberi dosis P2 juga lebih banyak dari pada tanaman padi yang dipupuk dosis $\mathrm{P} 1$.

Jumlah Biji Per Malai
Jumlah biji per malai dapat diketahui dari semua biji pada semua malai dari masing-masing perlakuan (Indriatama et al., 2017). Tabel 4 menunjukan bahwa tidak terjadi pengaruh interaksi yang nyata antara perlakuan model jarak tanam dengan dosis pupuk bokasi. Namun, semua model percobaan berpengaruh nyata terhadap jumlah biji per malai. Pengaruh perlakuan model jarak tanam dan dosis bokasi terhadap jumlah biji per malai padi disajikan pada Tabel 5.

Tabel 5. Rata-rata jumlah biji per malai akibat berbagai perlakuan model

\begin{tabular}{|c|c|c|}
\hline Perlakuan & Jumlah Biji Per Mal & \\
\hline J1 & 139,11 & $\mathrm{a}$ \\
\hline J2 & 170,78 & $b$ \\
\hline J3 & 152,22 & $b$ \\
\hline BNT 5\% & 7,44 & \\
\hline $\mathrm{P} 1$ & 141,67 & $\mathrm{a}$ \\
\hline P2 & 154,33 & $b$ \\
\hline P3 & 166,11 & c \\
\hline BNT 5\% & 7,44 & \\
\hline
\end{tabular}

Keterangan : Angka-angka diikuti oleh huruf yang sama pada kolom yang sama tidak berbeda nyata pada uji BNT ( $\mathrm{pl}=0,05$ )

Tabel 5 menunjukan bahwa perlakuan model jarak tanam jajar legowo J2 dan J3 menghasilkan jumlah jumlah biji per malai lebih banyak bila dibanding dengan perlakuan model $\mathrm{J} 1$. Hal ini disebabkan karena pada perlakuan jajar legowo dapat menyebabkan sinar matahari masuk ke dalam pertanaman lebih leluasa dari pada perlakuan model jarak tanam tegel (Indrawan et al., 2017). Sehingga pertumbuhan tanaman pada perlakuan jajar legowo lebih baik dan proses imbisi biji dapat berjalan lancer. Sehingga biji per malai yang dihasilkan juga lebih banyak. Perlakuan J2 menghasilkan jumlah biji per malai yang lebih banyak dari pada perlakuan $\mathrm{J} 3$, karena pada perlakuan J2 menghasilkan ruang untuk masuknya sinar matahari ke pertanaman lebih banyak bila dibandingkan dengan perlakuan J2, sehingga jumlah jumlah biji per malai yang dihasilkan oleh perlakuan J3 lebih banyak dari pada perlakuan J3.

Dosis pupuk bokasi berpengaruh terhadap jumlah biji per malai. Jumlah biji per malai yang dihasilkan model P2 lebih banyak dari pada tanaman padi yang beri pupuk bokasi 5 ton/ha (P1), sedang tanaman padi yang diberi pupuk bokasi 15 ton/ha (P3) menghasilkan jumlah biji per malai lebih banyak dari pada tanaman padi yang diberi pupuk bokasi 10 ton/ha (P2). Semakin tinggi dosis pupuk bokasi yang diberikan pada tanaman padi biji per malai yang dihasilkan oleh perlakuan dosis bokasi 
15 ton/ha lebih banyak bila dibandingkan dengan tanaman yang dipupuk bokasi dengan dosis 10 ton/ha. Jumlah biji per malai yang dihasilkan oleh tanaman yang diberi pupuk bokasi 10 ton/ha juga lebih banyak dari pada tanaman padi yang dipupuk bokasi 5 ton/ha..

Panjang Malai

Tabel 5 menunjukkan bahwa tidak terjadi pengaruh interaksi yang nyata antara perlakuan model jarak tanam dan dosis pupuk bokasi terhadap panjang malai, tetapi masing-masing perlakuan secara terpisah berpengaruh nyata terhadap panjang malai.

Hasil uji beda nyata terkecil (BNT) 5\% terhadap panjang malai tanaman padi disajikan pada tabel 6 berikut ini.

Tabel 6. Rata-rata panjang malai $(\mathrm{cm})$ tanaman padi pada perlakuan model jarak tanam dan dosis bokasi

\begin{tabular}{|c|c|c|}
\hline Perlakuan & Panjang Malai & $(\mathbf{c m})$ \\
\hline J1 & 18,78 & $a$ \\
\hline J2 & 22,78 & $\mathrm{C}$ \\
\hline J3 & 20,89 & $\mathrm{~b}$ \\
\hline BNT 5\% & 1,46 & \\
\hline P1 & 19,56 & $a$ \\
\hline P2 & 21,00 & $a b$ \\
\hline P3 & 21,89 & $\mathrm{~b}$ \\
\hline BNT 5\% & 1,46 & \\
\hline
\end{tabular}

Keterangan : Angka-angka diikuti oleh huruf yang sama pada kolom yang sama tidak berbeda nyata pada uji BNT ( $\mathrm{pl}=0,05$ )

Tabel 6 diatas memperlihatkan bahwa perlakuan model jarak tanam dan dosis pupuk kandang berpengaruh nyata terhadap panjang malai. Perlakuan J2, diikuti oleh perlakuan J3 kemudian yang paling jelek atau paling pendek malainya adalah model J1. Hal ini dikarenakan pada perlakuan model jajar legowo 4;1 menghasilkan pertumbuhan tanaman padi yang lebih baik dari pada perlakuan model jajar legowo 2;1. Sedangkan pertumbuhan tanaman padi model jarak tanam jajar legowo 2;1 lebih baik dari pada model tegel.

\section{Berat Gabah Per Malai}

Tabel 7 menunjukkan perlakuan model jarak tanam dan dosis pupuk bokasi secara terpisah berpengaruh nyata terhadap berat gabah per malai, tetapi tidak terjadi interaksi yang nyata diantara kedua perlakuan tersebut. Pengaruh model jarak tanam dan dosis bokasi terhadap berat gabah per malai disajikan pada Tabel 7 .

Tabel 7. Rata-rata berat gabah per malai (gr) pada perlakuan model jarak tanam dan dosis pupuk bokasi.

\begin{tabular}{|c|c|}
\hline Perlakuan & Berat Gabah Per Malai (gr) \\
\hline J1 & $6,38 \quad a$ \\
\hline J2 & $9.34 \quad b$ \\
\hline J3 & $7,71 \mathrm{c}$ \\
\hline BNT 5\% & 1,26 \\
\hline
\end{tabular}


Junaidi \& Djoko Rahardjo, Upaya Optimalisasi Hasil...

\begin{tabular}{cll}
\hline P1 & 6,59 & $\mathrm{a}$ \\
P2 & 7,99 & $\mathrm{~b}$ \\
P3 & 8,86 & $\mathrm{c}$ \\
\hline BNT 5\% & 1,26 &
\end{tabular}

Keterangan : Angka-angka diikuti oleh huruf yang sama pada kolom yang sama tidak berbeda nyata pada uji BNT ( $\mathrm{pl}=0,05$ )

Dari Tabel 7 diatas dapat diketahui bahwa berat gabah malai yang dihasilkan oleh perlakuan model jarak tanam terkecil dihasilkan oleh perlakuan model J1, sedangkan berat gabah per malai tertinggi dihasilkan oleh model $\mathrm{J} 2$. Hal ini disebabkan karena perlakuan J3 menghasilkan pertumbuhan tanaman padi yang paling baik, diikuti oleh model J2 dan yang terendah adalah perlakuan model tegel.

Perlakuan dosis P3 menghasilkan berat gabah per malai lebih tinggi dari pada tanaman padi yang diberi dosis $\mathrm{P} 2$, sedang berat gabah per malai yang

paling rendah dihasilkan oleh perlakuan dosis P1. Hal ini berarti pemberian dosis pupuk bokasi yang lebih banyak menghasilkan pertumbuhan tanaman padi lebih bagus, sehingga hasil gabah per malai juga lebih tinggi.

\section{Berat Gabah Per Rumpun}

Tabel 7 menunjukan terjadi interaksi yang sangat nyata antara perlakuan model jarak tanam dan dosis pupuk bokasi terhadap berat gabah per rumpun. Hasil uji beda nyata terkecil BNT 5\% berat gabah per rumpun disajikan pada Tabel 8 berikut ini.

Tabel 8. Pengaruh berbagai perlakuan terhadap berat gabah per rumpun (gr).

\begin{tabular}{crl}
\hline Perlakuan & Berat Gabah Per Rumpun (gr) \\
\hline J1 P1 & 70,27 & $\mathrm{a}$ \\
J1 P2 & 122,77 & $\mathrm{~b}$ \\
J1 P3 & 128,20 & $\mathrm{~b}$ \\
J2 P1 & 119,30 & $\mathrm{~b}$ \\
J2 P2 & 146,40 & $\mathrm{bc}$ \\
J2 P3 & 282,17 & $\mathrm{e}$ \\
J3 P1 & 174,60 & $\mathrm{~cd}$ \\
J3 P2 & 149,47 & $\mathrm{bc}$ \\
J3 P3 & 205,60 & $\mathrm{~d}$ \\
\hline BNT 5\% & 32,98 &
\end{tabular}

Keterangan : Angka-angka diikuti oleh huruf yang sama pada kolom yang sama tidak berbeda nyata pada uji BNT ( $\mathrm{pl}=0,05$ )

Tabel 8 Menunjukan kombinasi perlakuan model $\mathrm{J} 2$ dan dosis P3 mengasilkan berat gabah per rumpun paling tinggi $(282,17 \mathrm{gr})$. Karena perlakuan J2 menyebabkan tingkat kompetisi antar tanaman padi lebih rendah. Selain itu perlakuan model J2 menyebabkan sinar matahari bisa lebih leluasa masuk kedalam pertanaman padi. Keadaan yang baik ini diikuti dengan penambahan dosis pupuk bokasi yang lebih banyak menyebabkan kondisi lahan pertanaman padi menjadi lebih baik, sehingga proses perkembangan tanaman padi menjadi lebih baik, proses pengisian biji lancer, dan berat gabah per rumpun juga lebih banyak. 
Junaidi \& Djoko Rahardjo, Upaya Optimalisasi Hasil...

Berat Gabah Per Petak

Hasil analisis ragam Tabel 9 menunjukan bahwa Secara individu perlakuan model jarak tanam dan dosis pupuk kandang berpengaruh nyata terhadap berat gabah per petak, tetapi diantara kedua perlakuan tersebut tidak menunjukan adanya pengaruh interaksi yang nyata. Hasil uji beda nyata terkecil BNT 5\% terhadap berat malai tanaman padi disajikan pada Tabel 9 berikut ini.

Tabel 9. Rata-rata berat gabah per petak $(\mathrm{Kg})$ pada berbagai perlakuan

\begin{tabular}{|c|c|c|}
\hline Perlakuan & \multicolumn{2}{|c|}{ Berat Gabah Per Petak (Kg) } \\
\hline J1 & 6,38 & $a$ \\
\hline $\mathrm{J} 2$ & 7,71 & b \\
\hline J3 & 9,34 & c \\
\hline BNT 5\% & 1,26 & \\
\hline $\mathrm{P} 1$ & 6,59 & $a$ \\
\hline P2 & 7,99 & b \\
\hline P3 & 8,86 & c \\
\hline BNT 5\% & 1,26 & \\
\hline
\end{tabular}

Keterangan : Angka-angka diikuti oleh huruf yang sama pada kolom yang sama tidak berbeda nyata pada uji BNT ( $\mathrm{pl}=0,05$ )

Tabel 9 diatas menunjukkan bahwa perlakuan model J2 menghasilkan berat gabah perpetak lebih tinggi yaitu $7,71 \mathrm{~kg}$ dari pada model J1 yang hanya $6,38 \mathrm{~kg}$, sedang perlakuan model $\mathrm{J} 3$ mengasilkan berat gabah per petak lebih tinggi dari pada model J2 yaitu 9,34 kg. Hal ini dimungkinkan karena model J3 menyebabkan penyinaran terhadap tanaman padi lebih baik dari jumlah tanaman per petak lebih banyak dari pada perlakuan model J1. Sedangan jika dibandingkan dengan model J2, maka walaupun pada model J3 pertumbuhan dan produksi pertanamannya lebih baik daripada Model J3, tetapi jumlah tanaman perpetaknya lebih sedikit, sehingga berat gabah per petak tertinggi dihasilkan oleh model J3.

Perlakuan dosis bokasi paling tinggi menyebabkan lahan memiliki tingkat kesuburan yang lebih baik, baik kesuburan secara fisik, kimiawi maupun biologi, sehingga pertumbuhan tanaman yang dipupuk bokasi lebih banyak lebih baik, dan akhirnya produksi yang dihasilkan juba lebih banyak. Perlakuan dosis pupuk bokasi 5 ton/ha menghasilkan berat gabah per petak paling sedikit yaitu $6,59 \mathrm{~kg}$, sedangkan berat gabah per petak yang paling tinggi dihasilkan oleh perlakuan dosis bokasi 15 ton/ha yaitu $8,86 \mathrm{~kg}$.

\section{KESIMPULAN}

Terdapat pengaruh interaksi pada berbagai perlakuan terhadap tinggi tanaman setiap umur pengamatan. Selain berbagai perlakuan itu juga memiliki pengaruh terhadap jumlah anakan, jumlah anakan produktif, jumlah biji permalai, panjang malai berat biji permalai, dan berat gabah per petak semua umur pengamatan. Perlakuan J2 menghasilkan pertumbuhan dan produksi padi sawah pertanaman paling baik, sedangkan produksi paling tinggi dihasilkan oleh model J3. Perlakuan dosis P3 menghasilkan pertumbuhan dan produksi padi sawah paling baik. 
Junaidi \& Djoko Rahardjo, Upaya Optimalisasi Hasil...

\section{DAFTAR PUSTAKA}

Aribawa, I. B. 2012. Pengaruh Sistem Tanam Terhadap Peningkatan Produktivitas Padi Di Lahan Sawah Dataran Tinggi Beriklim Basah. Seminar Nasional Kedaulatan Pangan Dan Energi.

Arifiani, F. N., Kurniasih, B., dan Rogomulyo, R. 2018. Pengaruh Bahan Organik terhadap Pertumbuhan dan Hasil Padi Tercekam Salinitas. Jurnal Vegetalika. 7(3): 30-40.

https://doi.org/10.22146/veg.38133

Auliana, A., Ridwan, I., dan Nurlina, N. 2018. Analisis Tingkat Kekritisan Lahan di DAS Tabunio Kabupaten Tanah Laut. Jurnal Positron. 7(2): $54-59$

https://doi.org/10.26418/positron.v7i 2.18671

Azahari, D. H., dan Hadiutomo, K. (2016). Analisis Keunggulan Komparatif Beras Indonesia. Jurnal Analisis Kebijakan Pertanian. 11(1): 61-73.

https://doi.org/10.21082/akp.v11n1. 2013.61-73

Badan Pusat Statistik. (2017). Kajian Konsumsi Bahan Pokok 2017. In Badan Pusat Statistik.

BPS dan BPPT. (2018). Luas Panen dan Produksi Padi di Indonesia 2017. In Acta Universitatis Agriculturae et Silviculturae Mendelianae Brunensis.

Hamid, I. (2019). Pengaruh perlakuan jarak tanam dan pemberian pupuk npk terhadap pertumbuhan dan produksi tanaman jagung (Zea mays L.). Agricultural Research Journal. 15(1):174-184.

Ikhwani, Pratiwi, G. R., Paturrohman, E., dan Makarim, A. K. (2013). Peningkatan Produktivitas Padi Melalui Penerapan Jarak Tanam Jajar Legowo (Increasing rice productivity through the implementation of legowo jajar spacing). Jurnal Iptek Tanaman Pangan. 8(2): 72 - 79.

Indrawan, R. R., Agus, S., dan Roedy, S. (2017). Kajian iklim mikro terhadap berbagai sistem tanam dan populasi tanaman jagung manis (Zea mays saccharata Sturt.). Jurnal Produksi Pertanian. 5(1): 92-99.

Indriatama, $\quad$ W. $\quad$ M., Trikoesoemaningtyas, T., lis Aisyah, S., \& Human, S. (2017). Pendugaan Ragam Genetik dan Heritabilitas Karakter Agronomi Gandum Hasil Tiga Perlakuan Teknik Iradiasi Sinar Gamma. Jurnal IImiah Aplikasi Isotop dan Radiasi. 12(2): 79-88. https://doi.org/10.17146/jair.2016.1 2.2.2861

Kebijakan Perdagangan Internasional Komoditas Pertanian Indonesia. (2017). Analisis Kebijakan Pertanian.

https://doi.org/10.21082/akp.v2n2.2 004.135-156

Kriswanto, H., Safriyanti, E., dan Bahri, S. (2016). Pemberian pupuk organik dan pupuk NPK pada tanaman jagung manis (Zea mays saccharata, Sturt). Jurnal Klorofi 
Junaidi \& Djoko Rahardjo, Upaya Optimalisasi Hasil...

11(1):

$1-6$. DOI:https://doi.org/10.32502/jk.v11i 1.29 .

Suyamto. 2017. Manfaat Bahan dan Pupuk Organik pada Tanaman Padi di Lahan Sawah Irigasi. Jurnal Iptek Tanaman Pangan. 12(2): 67 - 74.

Mariyono. 2017. Seleksi Massa Positif S1 Pada 12 Galur Kedelai Hasil Persilangan Varietas Wilis dan Ocumani. Jurnal Agrinika. 1(1): 111.

DOI:http://dx.doi.org/10.30737/agrin ika.v1i1.295.g240

Neneng, N. L., dan Jubaedah. 2014. Konservasi Tanah Menghadapu Perubahan Iklim. In Teknologi Peningkatan Cadangan Karbon Lahan Kering dan Potensinya Pada Skala Nasional.

Nurcahyani, A. A., dan Saptono, R. 2016. Identifikasi Kualitas Beras dengan Citra Digital. Scientific Journal of Informatics. https://doi.org/10.15294/sji.v2i1.453 0

Prabowo, R., dan Subantoro, R. 2017. Analisis Tanah Sebagai Indikator Tingkat Kesuburan Lahan Budidaya Pertanian di Kota Semarang. Jurnal IImiah Cendekia Eksakta.

Pratama, A. R., Sudrajat, S., dan Harini, R. 2019. Analisis Ketersediaan dan Kebutuhan Beras di Indonesia Tahun 2018. Jurnal Media Komunikasi Geografi. https://doi.org/10.23887/mkg.v20i2. 19256

Sari, M. N., Sudarsono, dan Darmawan. 2017. Pengaruh Bahan Organik
Terhadap Ketersediaan Fosfor pada Tanah-Tanah Kaya Al dan Fe. Jurnal Buletin Tanah Dan Lahan. 1(1): 65-71.

Silwasty Kotu, Jenny J. Rondonuwu, Sandra Pakasi, dan Tilda Titah. 2015. Status Unsur Hara dan PH Tanah di Desa Sea, Kecamatan Pineleng Kabupaten Minahasa.. Jurnal Cocos. 6(12): 1-10.

Sulaeman, Y., , M., dan Erfandi, D. 2017. Pengaruh Kombinasi Pupuk Organik dan Anorganik terhadap Sifat Kimia Tanah, dan Hasil Tanaman Jagung di Lahan Kering Masam. Jurnal Pengkajian Dan Pengembangan Teknologi Pertanian.

https://doi.org/10.21082/jpptp.v20n1 .2017.p1-12

Rozen, N., dan Kasim M. 2018. Teknik Budidaya Tanaman Padi Metode SRI. Depok: Rajawali Press.

Wahyudi, I., Kristia Dinata Sinaga, D., dan Binti Jasni, L. 2014. Pengaruh Jarak Tanam Terhadap Pertumbuhan Pohon dan Beberapa Sifat Fisis-Mekanis Kayu Jati Cepat Tumbuh (Spacing Effect on Tree Growth and Several PhysicalMechanical Properties of FasterGrown Teak Wood). Jurnal IImu Pertanian Indonesia (JIPI), Desember. 19(3): 204-210.

Winarsih, A., Respatijarti, dan Damanhuri. 2017. Karakterisasi Beberapa Genotip Padi ( Oryza sativa L .) Berkadar Antosianin Tinggi. Jurnal Produksi Tanaman. 5(7): 1070-1076. 